\title{
PENGARUH PEMBANGUNAN INFRASTRUKTUR TERHADAP PERTUMBUHAN EKONOMI DI PROVINSI BENGKULU
}

\author{
Azuwandri, Retno Agustina Ekaputri, Sunoto \\ Sekolah Tinggi Ilmu Administrasi (STIA) Bengkulu \\ Fakultas Ekonomi dan Bisnis Universitas Bengkulu \\ azuwandri24@gmail.com
}

\begin{abstract}
ABSTRAK
Azuwandri, Retno Agustina Ekaputri, Sunoto; Tujuan dari penelitian ini adalah untuk Menganalisis Efek Pembangunan Infrastruktur Jalan Panjang, Energi Listrik, Telepon dan Air terhadap Pertumbuhan Ekonomi. Metode analisis yang digunakan untuk mencapai tujuan ini adalah dengan menggunakan model analisis regresi PLS, Fixed Effects. Jenis data kunci yang digunakan data sekunder adalah kabupaten/ kota yang berlokasi di provinsi Bengkulu tahun 2009-2013. Hasil penelitian menggunakan 7.0 eviews Program menemukan bahwa faktor-faktor positif dan signifikan mempengaruhi pertumbuhan ekonomi selama tahun 2009-2013 Provinsi Bengkulu adalah variabel pengamatan panjang Jalan, Energi dan Air, meskipun variabel Telepon memiliki korelasi negatif, tetapi berpengaruh signifikan terhadap pertumbuhan ekonomi.
\end{abstract}

\section{ABSTRACT}

Azuwandri, Retno Agustina Ekaputri, Sunoto; The purpose of this study was to Analyze Effects of Long Road Infrastructure Development, Energy Electricity, Telephone and Water to Economic Growth. The analytical method used to achieve this goal is by using PLS regression analysis model Fixed Effects. Type of key data used secondary data is district / municipality located in the province of Bengkulu years 20092013. The result using 7.0 eviews Program found that the factors positively and significantly affect economic growth during the years 2009-2013 Bengkulu province is the observation variable length Roads, Energy and Water, although variable Phone has a negative correlation, but a significant impact on economic growth.

\section{Keywords; Economic Growth, Long Road, the Energy Electricity, Telephone and Water, Regression Analysis}

\section{LATAR BELAKANG}

Pembangunan ekonomi daerah merupakan salah satu bagian penting dari pembangunan ekonomi nasional. Tujuan akhir dari pembangunan ekonomi tersebut adalah untuk meningkatkan kesejahteraan masyarakat. Todaro megatakan bahwa keberhasilan pembangunan ekonomi ditunjukkan oleh 3 nilai pokok yaitu: berkembangnya kemampuan masyarakat untuk memenuhi kebutuhan pokoknya, meningkatnya rasa harga diri masyarakat sebagai manusia, dan meningkatnya kemampuan masyarakat untuk memilih (Arsyad: 1997).

Supaya masyarakat mampu memenuhi kebutuhan pokoknya, kegiatan ekonomi harus didukung oleh infrastruktur yang memadai sehingga mendorong peningkatan potensi daerah secara berkesinambungan. Infrastruktur biasanya diselenggarakan oleh pemerintah karena sifatnya yang dibutuhkan oleh masyarakat luas. Namun dalam penyediaannya pemerintah dapat bekerja sama dengan badan usaha sesuai dengan Peraturan Presiden Republik Indonesia Nomor 67 Tahun 2005 tentang Kerjasama Pemerintah dengan Badan Usaha dalam Penyediaan Infrastruktur.

Dalam penyediaan infrastruktur, pemerintah mempunyai peranan yang sangat penting, walaupun pengadaan infrastruktur bisa dilakukan melalui kerja sama dengan badan usaha yang telah ditunjuk, tetapi tidak semua layanan infrastruktur bisa dilaksanakan oleh pihak swasta karena ada layanan infrastruktur yang memerlukan modal yang besar dengan waktu pengembalian yang lama dan resiko investasi yang besar. Peningkatan prasarana infrastruktur diharapkan dapat membawa kesejahteraan dan mempercepat pembangunan ekonomi karena kegiatan perekonomian akan lebih efisien. Dengan demikian pemerintah dituntut untuk menyediakan sarana dan prasarana untuk menunjang perekonomian. Dengan adanya fasilitas publik, pihak swasta menjadi berminat untuk menanamkan modal.

Infrastruktur merupakan aset pemerintah yang dibangun dalam rangka memberikan pelayanan kepada masyarakat seperti jalan raya, jembatan, pertamanan, gedung kantor, rumah sakit dan 
sebagainya. Infrastruktur ini kemudian dimanfaatkan oleh masyarakat untuk melakukan kegiatan sosial maupun ekonomi. Ernawi (2007) menyatakan bahwa kegiatan ekonomi masyarakat disuatu negara tidak akan berjalan optimal tanpa didukung infrastruktur yang memadai.

Menurut Arsyad (1997) ketersediaan infrastruktur sangat menentukan kesuksessan suatu daerah dalam proses produksi, memperluas perdagangan, mengurangi kemiskinan, mengatasi pertumbuhan penduduk, menarik investasi dan memperbaiki kondisi lingkungan. Adanya kenyataan bahwa pertumbuhan ekonomi suatu daerah erat kaitannya dengan penyediaan infrastruktur yang ada di daerah tersebut, mengindikasikan bahwa penyediaan infrastruktur sangat diperlukan untuk meningkatkan kemakmuran daerah.

Demi tersedianya infrastruktur yang baik yang dapat meningkatkan kemakmuran masyarakat Provinsi Bengkulu diperlukan suatu pembangunan yang merata dan menyeluruh diseluruh daerah. Sehingga dengan pemerataan dan fasilitas yang memadai dapat meningkatkan perekonomian yang lebih baik. Menurut Harrod-Domar, setiap perekonomian dapat menyisihkan suatu proporsi tertentu dari pendapatan nasionalnya jika hanya untuk mengganti barang-barang modal yang rusak. Namun demikian untuk menumbuhkan perekonomian tersebut, diperlukan investasi-investasi baru sebagai tambahan stok modal. Hubungan tersebut telah kita kenal dengan istilah rasio modal-output (COR). Dalam teori ini disebutkan bahwa, jika ingin tumbuh, perekonomian harus menabung dan menginvestasikan suatu proporsi tertentu dari output totalnya. Semakin banyak tabungan dan kemudian di investasikan, maka semakin cepat perekonomian itu akan tumbuh (Lincolyn, 2004).

Apakah pembangunan infrastruktur juga akan berpengaruh sama terhadap pertumbuhan ekonomi di Provinsi Bengkulu, membutuhkan penelitian lebih lanjut. Berikut ini akan diuraikan kondisi infrastruktur di Provinsi Bengkulu, baik infrastruktur listrik, telepon, air bersih maupun jalan untuk transportasi.

Dari ketersediaan air minum yang disuplai oleh pemerintah, PAM masih belum menjangkau wilayah-wilayah di Provinsi Bengkulu. Berdasarkan data Statistik, banyaknya Rumah Tangga Menurut Kabupaten/Kota dan Sumber Air Minum di Provinsi Bengkulu adalah sebagai beriku:

Tabel 1. Persentase Rumah Tangga Yang Menggunakan Ledeng Menurut Kabupaten/Kota di Provinsi Bengkulu pada Tahun 2009-2013 (dalam \%).

\begin{tabular}{rlccccc}
\hline \multirow{2}{*}{ NO } & \multirow{2}{*}{ KABUPATEN/KOTA } & \multicolumn{5}{c}{ LEDENG } \\
\cline { 3 - 7 } & & $\mathbf{2 0 0 9}$ & $\mathbf{2 0 1 0}$ & $\mathbf{2 0 1 1}$ & $\mathbf{2 0 1 2}$ & $\mathbf{2 0 1 3}$ \\
\hline 1 & Bengkulu Selatan & 2.77 & 3.60 & 4.10 & 3.36 & 0.80 \\
2 & Rejang Lebong & 14.96 & 18.85 & 15.20 & 16.14 & 14.17 \\
3 & Bengkulu Utara & 11.82 & 14.61 & 14.31 & 16.93 & 14.78 \\
4 & Kaur & 5.09 & 2.36 & 0.27 & 0.63 & 2.38 \\
5 & Seluma & 0.35 & 0.65 & 0.59 & 0.00 & 0.41 \\
6 & Mukomuko & 4.14 & 0.85 & 0.59 & 1.82 & 0.00 \\
7 & Lebong & 0.00 & 27.33 & 24.68 & 22.10 & 16.65 \\
8 & Kepahiang & 13.14 & 12.21 & 7.10 & 11.39 & 13.00 \\
9 & Bengkulu Tengah & 1.08 & 2.12 & 2.52 & 3.68 & 4.99 \\
10 & Kota Bengkulu & 23.80 & 19.76 & 14.94 & 15.94 & 11.42 \\
\hline & Provinsi Bengkulu & $\mathbf{7 7 . 1 5}$ & $\mathbf{1 0 2 . 3 4}$ & $\mathbf{8 4 . 3}$ & $\mathbf{9 1 . 9 9}$ & $\mathbf{7 8 , 6}$ \\
\hline
\end{tabular}

Sumber : BPS Provinsi Bengkulu

Dari tabel 1. diatas, dapat dilihat bahwa masih banyak masyarakat di suatu wilayah yang memakai sumber air minum lain selain PAM. Dari 472.800 rumah tangga di kota Bengkulu, sebanyak 11.420 rumah tanga berlangganan PAM. Padahal Kota Bengkulu adalah ibukota dari Provinsi Bengkulu. Namun ternyata hanya $4.14 \%$ rumah tangga yang menggunakan PAM sebagai sumber air minum. Hal ini bisa jadi penyediaan PAM yang belum merata di Provinsi Bengkulu, atau mungkin karena kualitas air PAM yang masih kurang bersih dan tidak sesuai untuk dipakai sebagai sumber air minum.

Selain air bersih yang disalurkan, salah satu pembangunan infrastruktur yang dapat meningkatkan pertumbuhan ekonomi adalah panjang jalan. Menurut Berdan (1989) dan Polanyi (1957) dalam Setiawan (2006), lalu lintas transportasi dapat merangsang tumbuhnya pasar dan pusatpusat pertumbuhan ekonomi atau sebaliknya. Jalur lalu lintas juga merupakan pembuka bagi masuknya jaringan listrik, telekomunikasi dan transportasi. Secara sosial, jalan dapat menjadi media interaksi sosial ekonomi antar satu daerah dengan daerah lainnya. Dengan demikian, jalan yang 
memadai sangat dibutuhkan keberadaannya untuk mendukung perekonomian di suatu daerah. Pada tabel 2. dibawah ini dapat dilihat bagaimana kondisi jalan Provinsi Bengkulu tiap tahunnya.

Tabel 2. Panjang Jalan Provinsi Menurut Kabupaten/Kota Dalam Kondisi Baik di Provinsi Bengkulu pada Tahun 2009-2013 (Km).

\begin{tabular}{rlccccc}
\hline \multirow{2}{*}{ NO } & \multirow{2}{*}{ KABUPATEN/KOTA } & \multicolumn{5}{c}{ KONDISI JALAN BAIK } \\
\cline { 3 - 6 } & & $\mathbf{2 0 0 9}$ & $\mathbf{2 0 1 0}$ & $\mathbf{2 0 1 1}$ & $\mathbf{2 0 1 2}$ & $\mathbf{2 0 1 3}$ \\
\hline 1 & Bengkulu Selatan & 539.75 & 156.60 & 277.15 & 689.53 & 663.76 \\
2 & Rejang Lebong & 286.23 & 303.23 & 423.11 & 456.50 & 509.34 \\
3 & Bengkulu Utara & 67.7 & 429.65 & 290.66 & 210.69 & 256.24 \\
4 & Kaur & 76.04 & 199.18 & 112.11 & 312.94 & 771.65 \\
5 & Seluma & 196.00 & 11.00 & 347.00 & 532.86 & 532.86 \\
6 & Mukomuko & 219.65 & 613.56 & 394.07 & 519.63 & 540.42 \\
7 & Lebong & 121.93 & 20.50 & 176.37 & 205.37 & 207.77 \\
8 & Kepahiang & 384.86 & 423.35 & 465.68 & 298.33 & 485.24 \\
9 & Bengkulu Tengah & 300.20 & 209.30 & 110.25 & 309.35 & 506.40 \\
10 & Kota Bengkulu & 401.65 & 303.90 & 387.80 & 535.89 & 569.61 \\
\hline \multicolumn{2}{c}{ Provinsi Bengkulu } & $\mathbf{2 . 5 9 4 , 0 1}$ & $\mathbf{2 . 6 7 0 , 2 7}$ & $\mathbf{2 . 9 8 4 , 2}$ & $\mathbf{4 . 0 7 1 , 0 9}$ & $\mathbf{5 . 0 4 3 , 2 9}$ \\
\hline
\end{tabular}

Infrastruktur transportasi merupakan prasyarat bagi pertumbuhan ekonomi. Keberadaan infrastruktur transportasi dapat menstimulasi aktivitas ekonomi dan akhirnya akan meningkatkan pertumbuhan ekonomi wilayah. Berdasarkan tabel 2. diatas menjelaskan bahwa pembangunan infrastruktur jalan setiap tahunnya, yaitu pada tahun 2009 sebesar 2.594,01 dan pada tahun 2013 mengalami peningkatan yang cukup tinggi sebesar 5.043,29. Namun untuk kabupaten Seluma, pembangunan infrastruktur jalan cukup kecil yaitu pada tahun 2010 sebesar $11.00 \mathrm{Km}$ dan untuk kabupaten Lebong pada tahun 2010 sebesar $20.50 \mathrm{Km}$. Keadan ini disebabkan karena penggunaan jalan yang digunakan untuk angkutan barang melebihi kapasitas yang tidak sesuai dengan kemampuan jalan, akibatnya banyak jalan yang rusak begitu parah.

Menurut Sulistyo (2011), pertumbuhan ekonomi yang baik harus didukung infrastruktur transportasi yang cukup memadai. Kondisi transportasi di Indonesia masih jauh dari kondisi yang ideal, untuk itu perlu dibuat strategi dan terobosan yang tepat untuk memajukan transportasi. Infrastruktur transportasi di Indonesia memberikan kontribusi sekitar 3,81\% bagi pertumbuhan ekonomi. Kondisi tersebut masih jauh dibawah negara maju yang mampu memberikan kontribusi sebesar $12 \%$.

Tabel 3. Jumlah Kwh Terjual Tiap Cabang Unit di Provinsi Bengkulu Tahun 2009-2013 (000Kwh)

\begin{tabular}{rlccccc}
\hline \multirow{2}{*}{ NO } & \multirow{2}{*}{ KABUPATEN/KOTA A } & \multicolumn{5}{c}{ KWH TERJUAL (KWH) } \\
\cline { 3 - 7 } & & $\mathbf{2 0 0 9}$ & $\mathbf{2 0 1 0}$ & $\mathbf{2 0 1 1}$ & $\mathbf{2 0 1 2}$ & $\mathbf{2 0 1 3}$ \\
\hline 1 & Bengkulu Selatan & 22.811 .854 & 27.927 .339 & 27.290 .298 & 102.306 .223 & 50.552 .701 \\
2 & Rejang Lebong & 54.198 .937 & 59.456 .335 & 58.531 .578 & 69.709 .742 & 77.118 .296 \\
3 & Bengkulu Utara & 35.108 .586 & 39.020 .446 & 44.909 .402 & 50.019 .065 & 54.929 .965 \\
4 & Kaur & 12.309 .024 & 14.568 .634 & 17.222 .319 & 21.406 .156 & 24.104 .860 \\
5 & Seluma & 25.895 .265 & 30.757 .449 & 33.062 .311 & 39.454 .693 & 44.258 .938 \\
6 & Mukomuko & 14.495 .811 & 20.015 .981 & 25.481 .076 & 37.952 .547 & 51.077 .471 \\
7 & Lebong & 13.238 .773 & 14.451 .283 & 17.938 .142 & 19.472 .170 & 22.445 .675 \\
8 & Kepahiang & 37.878 .741 & 41.466 .180 & 26.438 .454 & 50.697 .583 & 65.447 .345 \\
9 & Bengkulu Tengah & 0 & 0 & 27.532 .285 & 30.232 .150 & 56.280 .008 \\
10 & Kota Bengkulu & 171.434 .148 & 196.900 .449 & 482.844 .603 & 237.740 .904 & 260.745 .288 \\
\hline & Provinsi Bengkulu & $\mathbf{3 8 7 . 3 7 1 . 1 3 9}$ & $\mathbf{4 4 4 . 5 6 4 . 0 9 6}$ & $\mathbf{7 6 1 . 2 5 0 . 4 6 8}$ & $\mathbf{6 5 8 . 9 9 1 . 2 3 3}$ & $\mathbf{7 0 6 . 9 6 0 . 5 4 7}$ \\
\hline
\end{tabular}

Sumber : BPS Provinsi Bengkulu

Dari Tabel 3. diatas, dapat dilihat bahwa penyaluran Energi Listrik setiap tahunnya mengalami peningkatan. Peningkatan Listrik PLN terbesar dapat dilihat di Kota Bengkulu pada tahun 2011 
sebesar 761.250.468. Namun disetiap Kabupaten penyaluran Listrik PLN masih sangat kurang. Terutama di Kabupaten Kaur dan Lebong penyaluran energi listrik sangat kecil yaitu pada tahun 2011 Kabupaten Kaur sebesar 17.222.319 Kwh dan Lebong sebesar 17.938.142 Kwh. Masih Banyak masyarakat yang menggunakan Listrik Non PLN dalam kehidupannya sehari-hari, ini dikarenakan penyaluran pembangunan infrastruktur Listrik PLN belum merata dan pasokan energi listrik masih sangat kurang.

Tabel 4. Persentase Rumah Tangga menurut Kabupaten/kota dan Apakah Rumah Tangga ini ada Telepon Rumah di Provinsi Bengkulu Tahun 2009 - 2013(dalam \%)

\begin{tabular}{rlccccc}
\hline \multirow{2}{*}{ NO } & \multirow{2}{*}{ KABUPATEN/KOTA } & \multicolumn{5}{c}{ Yang Menggunakan Telepon } \\
\cline { 3 - 6 } & & $\mathbf{2 0 0 9}$ & $\mathbf{2 0 1 0}$ & $\mathbf{2 0 1 1}$ & $\mathbf{2 0 1 2}$ & $\mathbf{2 0 1 3}$ \\
\hline 1 & Bengkulu Selatan & 5,06 & 3,63 & 5,00 & 3,40 & 4,07 \\
2 & Rejang Lebong & 7,32 & 3,97 & 5,62 & 3,64 & 1,75 \\
3 & Bengkulu Utara & 3,84 & 5,77 & 7,41 & 1,24 & 4,24 \\
4 & Kaur & 1,32 & 1,46 & 1,15 & 2,70 & 0,87 \\
5 & Seluma & 2,30 & 1,33 & 0,76 & 1,35 & 2,61 \\
6 & Mukomuko & 2,38 & 1,24 & 2,22 & 1,72 & 1,63 \\
7 & Lebong & 3,42 & 2,25 & 1,13 & 2,12 & 2,59 \\
8 & Kepahiang & 2,35 & 3,55 & 2,25 & 2,99 & 3,17 \\
9 & Bengkulu Tengah & - & 1,50 & 3,16 & 2,52 & 3,80 \\
10 & Kota Bengkulu & 21,06 & 17,04 & 17,43 & 11,11 & 13,30 \\
\hline & Provinsi Bengkulu & $\mathbf{4 9 , 0 5}$ & $\mathbf{4 1 , 7 4}$ & $\mathbf{4 6 , 1 3}$ & $\mathbf{3 2 , 7 9}$ & $\mathbf{3 8 , 0 3}$ \\
\hline
\end{tabular}

Sumber : BPS Provinsi Bengkulu

Dari tabel 4. diatas, dapat dilihat bahwa rumah tangga menurut kabupaten/kota yang menggunakan telepon setiap tahun tahunnya mengalami penurunan. Pada tahun 2009 penggunaan telepon sangat tinggi sebesar 49,05\% dan pada tahun 2010 mulai mengalami fluktuatif sebesar 41,745, dan pada tahun 2011 mengalami peningkatan sebesar 46,13\%. Penurunan paling tinggi terjadi pada tahun 2012 yaitu sebesar 32,79\% dan pada tahun 2013 mengalami peningkatan sebesar 38,03\%.

Pembangunan sektor telekomunikasi juga masih menghadapi berbagai tantangan, salah satu tantangan tersebut adalah kemampuan untuk mengikuti perkembangan sektor telekomunikasi beserta pemanfaatannya berdasarkan daya dukung regulasi, potensi bisnis dan tingkat kemampuan pemecahan permasalahannya. Tantangan lainnya adalah pembangunan telekomunikasi saat ini masih terkonsentrasi di kota-kota besar, dan benturan permasalahan antara kalangan industri dengan pemerintah daerah. Selain itu, untuk menghadapi perubahan sehingga kehadiran teknologi baru di bidang telekomunikasi berikut dengan pemanfaatannya di masa mendatang dapat memberikan manfaat yang semaksimal mungkin untuk mencapai peningkatan dan kemajuan bangsa serta kesejahteraan segenap lapisan masyarakat.

Tabel 1.5. Laju Pertumbuhan PDRB Atas Dasar Harga Konstan menurut Kabupaten/Kota di Provinsi Bengkulu Tahun 2009 s/d 2013 (dalam persen)

\begin{tabular}{rlccccc}
\hline \multirow{2}{*}{ NO } & \multicolumn{2}{c}{ KABUPATEN/KOTA } & \multicolumn{5}{c}{ Pertumbuhan PDRB ADHK } \\
\cline { 3 - 6 } & & $\mathbf{2 0 0 9}$ & $\mathbf{2 0 1 0}$ & $\mathbf{2 0 1 1}$ & $\mathbf{2 0 1 2}$ & $\mathbf{2 0 1 3}$ \\
\hline 1 & Bengkulu Selata & 4.67 & 5.71 & 6.51 & 6.42 & 6.27 \\
2 & Rejang Lebong & 5.80 & 6.14 & 6.52 & 6.67 & 6.12 \\
3 & Bengkulu Utara & 4.84 & 5.03 & 5.96 & 6.13 & 5.58 \\
4 & Kaur & 4.27 & 4.19 & 4.84 & 5.54 & 5.98 \\
5 & Seluma & 5.23 & 5.30 & 5.41 & 5.73 & 5.29 \\
6 & Mukomuko & 4.25 & 5.27 & 5.86 & 6.64 & 6.05 \\
7 & Lebong & 4.46 & 5.26 & 5.71 & 5.94 & 5.62 \\
8 & Kepahiang & 5.71 & 5.93 & 6.14 & 6.60 & 6.01 \\
9 & Bengkulu Tengah & 4.37 & 5.64 & 6.13 & 6.74 & 5.37 \\
10 & Kota Bengkulu & 5.45 & 6.41 & 6.72 & 6.79 & 6.44 \\
\hline & Provinsi Bengkulu & 49.05 & 54.88 & 59.8 & 63.2 & 58.73 \\
\hline
\end{tabular}

Sumber : BPS Provinsi Bengkulu. 
Data yang langsung diperoleh (www.bi.go.id), berdasarkan Kajian Ekonomi Regional Provinsi Bengkulu, Perekonomian Bengkulu triwulan IV 2015 tumbuh 4.86\% lebih rendah dibandingkan triwulan sebelumnya sebesar 5.18\%. Sehingga secara kumulatif perekonomian Bengkulu tahun 2015 hanya tumbuh 5.14\% melambat dibandingkan pertumbuhan ekonomi tahun 2014 sebesar 5.47\%. Perlambatan ekonomi tersebut searah dengan perlambatan ekonomi Sumatera maupun Nasional.

Sementara itu, tekanan Inflasi pada triwulan IV 2015 melambat signifikan. Inflasi tercatat 3,25\% (yoy) lebih rendah dibandingkan triwulan sebelumnya yang mencapai 8,65\% (yoy). Kondisi ini didorong oleh meredanya tekanan inflasi pada kelompok administered prices dan volatile food. Hampir seluruh komoditas barang/jasa mengalami penurunan laju inflasi kecuali kelompok sandang; dan kelompok pendidikan, rekreasi, dan olahraga yang mengalami peningkatan.

Ditengah kondisi perlambatan ekonomi, kegiatan usaha perbankan di Bengkulu masih relatif terjaga. Hal ini tercermin dari pertumbuhan kredit UMKM yang meningkat dibandingkan periode sebelumnya. Dampak perlambatan ekonomi direspon secara terbatas pada pertumbuhan aset dan penghimpunan Dana Pihak Ketiga yang cenderung melambat dibandingkan triwulan sebelumnya. Stabilitas sistem keuangan masih dalam kondisi terjaga yang tercermin dari rasio kredit macet di level $2,23 \%$.

Perekonomian Triwulan I 2016 diperkirakan tumbuh sebesar 4,8-5,3\% meningkat dibandingkan triwulan IV 2015 yang tercatat hanya 4,86\%. Pertumbuhan bersumber dari konsumsi rumah tangga dan investasi yang didorong oleh kenaikan UMP di awal tahun dan mulai menurunnya suku bunga kredit perbankan.

Dengan permasalahan yang ada, pembangunan infrastruktur jalan disetiap kabupaten/kota tidak merata, masih banyak jalan di kabupaten yang rusak parah, begitu juga dengan ketersediaan pasokan energi listrik yang masih sangat terbatas. Belum terjangkaunya saluran telepon dan suplai air bersih diseluruh wilayah dan kabupaten di Provinsi Bengkulu karena masih kurang memenuhi kaidahkaidah teknis dan ekonomis sesuai dengan standar kriteria yang telah ditentukan. Padahal jalan, telepon, listrik dan air bersih merupakan sektor utama untuk menunjang kelangsungan peningkatan pertumbuhan ekonomi di Provinsi Bengkulu.

Berdasarkan latar belakang, maka perlu diadakan penelitian selanjutnya mengenai pengaruh pembangunan infrastruktur terhadap pertumbuhan ekonomi di Provinsi Bengkulu.

\section{Landasan Teori}

Landasan teori yang berkaitan dengan judul penelitian ini akan diuraikan pada teori mengenai peranan pemerintah dalam perekonomian, pertumbuhan ekonomi, model Neoklasik Solow, infrastruktur, barang publik, penelitian terdahulu dan kerangka analisis.

\section{Kerangka Analisis}

$$
\begin{aligned}
& \text { Infrastruktur } \\
& \text { Panjang Jalan } \\
& \text { Energi listrik yang terjual } \\
& \text { Telepon yang Terpasang } \\
& \text { Air Bersih yang Disalurkan }
\end{aligned}
$$

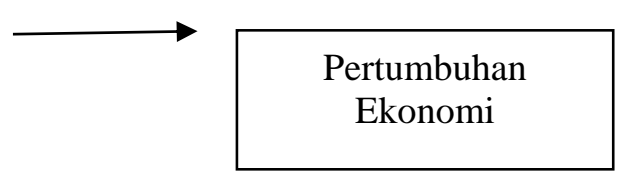

Gambar 1. Kerangka Analisis 


\section{Hipotesis}

Hipotesis yang diajukan dalam penelitian ini adalah bahwa diduga terdapat pengaruh yang siginifikan antara panjang jalan, energi listrik yang terjual, jumlah telepon dan jumlah air bersih yang disalurkan terhadap pertumbuhan ekonomi di Provinsi Bengkulu pada Tahun 2009-2013.

\section{HASIL PENELITIAN DAN PEMBAHASAN}

\section{Hasil Perhitungan}

Pada penelitian ini akan dilakukan analisis serta pembahasan terhadap pertumbuhan ekonomi di Provinsi Bengkulu sebagai dependent variabel, panjang jalan, energi listrik, telepon dan air bersih yang disalurkan, sebagai independent variabel.

Model dalam penelitian ini diestimasi menggunakan program Eviews 7.0. Adapun dasar analiis adalah pendekatan model fixed effect dengan metode Pooled Least Square (PLS) untuk masing-masing persamaan. Pendekatan fixed effect ini memberikan konstanta yang berbeda-beda pada masing-masing kabupaten. Hal ini menunjukkan karateristik yang berbeda antar kabupaten/kota di Provinsi bengkulu (lihat lampiran).

Data pada tabel 4.3 di bawah ini menunjukkan beberapa hasil estimasi model yang digunakan untuk melakukan pengujian secara parsial (uji t) maupun bersama-sama (uji F).

Tabel 4.3 Hasil Analisis Regresi Metode PLS (Cross-Section Fixed Effect).

\begin{tabular}{crrrr} 
Variable & Coefficient & Std. Error & t-Statistic & Prob. \\
\hline \hline C & 4.886708 & 0.220577 & 22.15425 & 0.0000 \\
PJ & 0.001495 & 0.000496 & 3.013079 & 0.0042 \\
EL & $3.96 \mathrm{E}-09$ & $1.81 \mathrm{E}-09$ & 2.191897 & 0.0336 \\
T & -0.041941 & 0.034353 & -1.220877 & 0.2285 \\
AB & 0.028458 & 0.012250 & 2.323185 & 0.0247 \\
\hline \hline
\end{tabular}

\begin{tabular}{lr}
\hline R-squared & 0.573179 \\
Prob(F-statistic) & 0.000256 \\
Sumber : Lampiran PLS (Cross-section fixed effect).
\end{tabular}

Pada Pengujian Model diatas, hasil estimasi uji t menggambarkan bahwa terdapat 3 variabel signifikan pada $\alpha=5 \%$, yaitu panjang jalan, energi listrik dan air bersih. Sementara 1 variabel lain yang tidak signifikan pada $\alpha=5 \%$ yaitu telepon. Dari hasil hasil estimasi, $\mathrm{R}^{2}$ yang dihasilkan dari estimasi persamaan dalam penelitian ini yakni hanya sebesar 0.50 persen selama masa periode pengamatan. Hal ini dapat diartikan bahwa variabel-variabel independent dalam penelitian ini hanya mampu menjelaskan sebesar 57.31 persen variabel dependent sementara sisanya sebesar 42.69 persen dijelaskan oleh variabel lain yang tidak diikut sertakan dalam model penelitian. Kemudian uji F dengan hasil estimasi sebesar 0.000256, menyatakan bahwa semua variabel Panjang Jalan, energi Listrik, Telepon dan Air Bersih berpengaruh signifikan pada $\alpha=5 \%$.

Kemudian peneliti melakukan pengujian terhadap beberapa model estimasi pada rgresi data panel. Pengujian dilakukan dengan menggunakan jenis model estimasi berupa model common effect dengan model fixed effect, dan model fixed effect dengan model random effect. Hasil terbaik dengan beberapa pengujian digunakan untuk merumuskan kesimpulan dalam penelitian ini. Dari hasil perhitungan dengan menggunakan estimasi model common effect dengan model fixed effect, dengan bantuan sofware Eviews 7.0, untuk menentukan pilihan estimasi yang digunakan yaitu dengan melakukan Uji Chow. Dari uji ini diharapkan dapat diketahui pilihan yang lebih tepat antara model common effect dengan model fixed effect. Pengujian yang dilakukan menggunakan Uji Chow yaitu :

$\mathrm{H}_{0}=$ model mengikuti common effect

$\mathrm{H}_{\alpha}=$ model mengikuti fixed effect

Hasil Uji Chow menunjukkan nilai probabilitas Cross Section F dan Chi Square adalah 0,0000 \& 0,0000 yang lebih kecil dari Alpha 0,05 sehingga kita menolak hipotesis nol. Jadi untuk Uji Chow, model yang terbaik (pemilahan) adalah model dengan metode Fixed Effect (lihat lampiran).

Kemudian dilanjutkan dengan melakukan teknik estimasi menggunakan model random effect. Dari hasil perhitungan dengan menggunakan model estimasi fixed effect dengan model random effect, dengan bantuan sofware Eviews 7.0, untuk menentukan pilihan estimasi yang digunakan maka dilakukan Uji Hausman. Dari uji ini diharapkan dapat diketahui pilihan yang lebih tepat antara model fixed effect dengan model random effect. 
Bedasarkan hasil Uji Hausman, menunjukkan bahwa hasil pengujian tersebut Prob-value 0,0000 sehingga $\mathrm{H}_{0}$ ditolak dan $\mathrm{H}_{\alpha}$ diterima. Dari hasil estimasi menunjukkan bahwa pendekatan model fixed effect lebih baik dibandingkan dengan pendekatan model random effect (lihat lampiran).

Setelah melalui Uji Chow dan Uji Hausman, dapat disimpulkan bahwa estimasi model yang terbaik adalah menggunakan model fixed effect. Sesuai dengan model yang telah dipilih oleh peneliti, berdasarkan hasil olahan data untuk estimasi persamaan pertumbuhan ekonomi Provinsi Bengkulu dengan model fixed effect, diperoleh hasil estimasi model yang menggambarkan bahwa terdapat tiga variabel yang signifikan pada $\alpha=5 \%$, yaitu Panjang jalan, Energi Listrik dan Air Bersih, serta terdapat 1 variabel yang tidak signifikan yaitu Telepon. Hasil estimasinya tersaji pada tabel 4.4 berikut ini :

Tabel 4.4 Hasil Analisis Regresi Metode PLS (Cross-Section Fixed Effect).

\begin{tabular}{crrrr}
\hline \hline Variable & Coefficient & Std. Error & t-Statistic & Prob. \\
\hline \hline C & 4.886708 & 0.220577 & 22.15425 & 0.0000 \\
PJ & 0.001495 & 0.000496 & 3.013079 & 0.0042 \\
EL & $3.96 \mathrm{E}-09$ & $1.81 \mathrm{E}-09$ & 2.191897 & 0.0336 \\
T & -0.041941 & 0.034353 & -1.220877 & 0.0585 \\
AB & 0.028458 & 0.012250 & 2.323185 & 0.0247 \\
\hline \hline
\end{tabular}

Sumber : Lampiran PLS (Cross-section fixed effect).

Model ekonometrika yang diperoleh dari hasil regresi tersebut adalah :

$P E_{i t}=\beta_{0}+\beta_{1} P_{j i t}+\beta_{2} E_{i t}+\beta_{3} T_{i t}+\beta_{4} A_{B} B_{i t}+\mu_{i t}$

$\mathrm{PE}_{\mathrm{it}}=4.886708+0.001495 \mathrm{PJ}_{\mathrm{it}}+3.96 \mathrm{E}-09 \mathrm{EL}_{\mathrm{it}}-0.041941 \mathrm{~T}_{\mathrm{it}}+0.028458 \mathrm{AB}_{\mathrm{it}}$

Pengujian Hipotesis

a. Pengujian Hipotesis secara Parsial (uji t)

Pengujian secara parsial menggunakan uji t yang merupakan uji pengaruh signifikan independent variabel terhadap dependent variabel secara individu.

Nilai Prob $<0,05$ (untuk nilai $\alpha=5 \%$ ), maka $\mathrm{H}_{0}$ ditolak

Nilai Prob $>0,05$ (untuk nilai $\alpha=5 \%$ ), maka $\mathrm{H}_{0}$ diterima

Nilai Probability variabel-variabel yang diuji ini diperoleh dari hasil regresi linier dengan metode PLS (Cross-section fixed effect).

1. Pengujian signifikan variabel Panjang Jalan (PJ) terhadap variabel Pertumbuhan Ekonomi

Dari hasil diperoleh bahwa nilai Probability adalah 0,0042. Sehingga diperoleh hasil Prob. $(0,0042<$ Prob. $t(0.05)$, maka keputusannya adalah Hipotesa null $\left(\mathrm{H}_{0}\right)$ akan ditolak dan $\mathrm{H}_{\alpha}$ akan diterima. Hasil dari uji t tersebut bahwa Panjang Jalan (PJ) berpengaruh positif dan signifikan secara statistik terhadap pertumbuhan ekonomi di Provinsi Bengkulu sesuai dengan hipotesis dan signifikan secara statistik. Sehingga dapat dinyatakan bahwa Panjang Jalan (PJ) berpengaruh secara signifikan terhadap pertumbuhan ekonomi di Provinsi Bengkulu.

2. Pengujian signifikan variabel Energi Listrik (EL) terhadap variabel Pertumbuhan Ekonomi Dari hasil diperoleh bahwa nilai Probability adalah 0,0336. Sehingga diperoleh hasil Prob. $(0,0336<$ Prob. $\mathrm{t}(0.05)$, maka keputusannya adalah Hipotesa null $\left(\mathrm{H}_{0}\right)$ akan ditolak dan $\mathrm{H}_{\alpha}$ akan diterima. Hasil dari uji t tersebut bahwa Energi Listrik (EL) berpengaruh positif dan signifikan secara statistik terhadap pertumbuhan ekonomi di Provinsi Bengkulu sesuai dengan hipotesis dan signifikan secara statistik. Sehingga dapat dinyatakan bahwa Energi Listrik (EL) berpengaruh secara signifikan terhadap pertumbuhan ekonomi di Provinsi Bengkulu.

3. Pengujian signifikan variabel Telepon (T) terhadap variabel Pertumbuhan Ekonomi

Dari hasil diperoleh bahwa nilai Probability adalah 0,0585. Sehingga diperoleh hasil Prob. $(0,0585>$ Prob. t (0.05), maka keputusannya adalah Hipotesa null ( $\left.\mathrm{H}_{0}\right)$ akan diterima. Hasil dari uji t tersebut bahwa Telepon ( $\mathrm{T}$ ) berpengaruh negatif dan signifikan secara statistik terhadap pertumbuhan ekonomi di Provinsi Bengkulu sesuai dengan hipotesis dan signifikan secara statistik. Sehingga dapat dinyatakan bahwa Telepon (T) berpengaruh secara signifikan terhadap pertumbuhan ekonomi di Provinsi Bengkulu namun memberikan dampak yang negatif.

4. Pengujian signifikan variabel Air Bersih (AB) terhadap variabel Pertumbuhan Ekonomi

Dari hasil diperoleh bahwa nilai Probability adalah 0,0247. Sehingga diperoleh hasil Prob. $(0,0247<$ Prob. $\mathrm{t}(0.05)$, maka keputusannya adalah Hipotesa null $\left(\mathrm{H}_{0}\right)$ akan ditolak dan $\mathrm{H}_{\alpha}$ akan diterima. Hasil dari uji t tersebut bahwa Air Bersih (AB) berpengaruh positif dan signifikan secara statistik terhadap pertumbuhan ekonomi di Provinsi Bengkulu sesuai dengan hipotesis dan signifikan secara statistik. 
Sehingga dapat dinyatakan bahwa Air Bersih (AB) berpengaruh secara signifikan terhadap pertumbuhan ekonomi di Provinsi Bengkulu.

b. Pengujian Hipotesis secara Serempak (uji F)

Pengujian secara serempak menggunakan uji F. Uji F bertujuan untuk menguji apakah independent variabel berpengaruh secara bersama-sama (menyeluruh) terhadap dependent variabel.

Nilai Prob (F-Statistic) $<0,05$ (untuk nilai $\alpha=5 \%$ ), maka $\mathrm{H}_{0}$ ditolak

Nilai Prob (F-Statistic) > 0,05 (untuk nilai $\alpha=5 \%$ ), maka $\mathrm{H}_{0}$ diterima

Hasil yang diperoleh yaitu nilai Prob (F-Statistic) $(0,000256)<$ Prob (F-Statistic) $(0,05)$, maka keputusannya adalah Hipotesa null $\left(\mathrm{H}_{0}\right)$ akan ditolak dan $\mathrm{H}_{\alpha}$ akan diterima. Sehingga hasil dari uji $\mathrm{F}$ menyatakan variabel Panjang Jalan, Energi Listrik, Telepon dan Air Bersih berpengaruh secara bersama-sama dan signifikan terhadap pertumbuhan ekonomi di Provinsi Bengkulu.

c. Koefisien Determinasi $\left(\mathbf{R}^{2}\right)$

Koefisien determinasi ini menunjukkan tingkat/derajat keakuratan hubungan antara independent variable dengan dependent variable. Dari hasil regresi diperoleh nilai $\mathrm{R}^{2}=0.573179$, yang berarti bahwa variable pertumbuhan ekonomi di Provinsi Bengkulu sebagai variabel dependen dapat dijelaskan oleh vaiabel-variabel independen yaitu Panjang Jalan, Energi Listrik, Telepon dan Air Bersih $57.31 \%$ dan sisanya $42.69 \%$ dijelaskan oleh variabel-variabel lain di luar model.

\section{Simpulan}

1. Panjang Jalan mempunyai hubungan positif dan signifikan terhadap pertumbuan ekonomi. Artinya, bahwa semakin baik kondisi jalan di Provinsi Bengkulu, maka akan mendorong naiknya petumbuhan ekonomi. Hal tersebut bermakna bahwa semakin banyak jalan yang diperbaiki dan merata disetiap wilayah maka akan meningkatkan pertumbuhan ekonomi, yang disebabkan kegiatan distribusi barang dan jasa berjalan dengan lancar dan mengalami peningkatan yang cukup besar.

2. Energi Listrik mempunyai pengarh yang positif dan signifikan terhadap pertumbuhan ekonomi. Artinya, bahwa semakin banyak energi listrik yang tersalurkan dan terpasang di Provinsi Bengkulu, maka akan mendorong naiknya pertumbuhan ekonomi. Pembangunan infrastruktur Listrik merupakan sebagai bentuk kebijakan fiskal dari pemerintah dalam upaya meningkatkan pembangunan dan pertumbuhan ekonomi.

3. Telepon mempunyai hubungan yang negatif namun signifikan terhadap pertumbuhan ekonomi, disebabkan karena pembangunan telepon ini menggunakan biaya yang cukup mahal dan juga output yang dihasilkan telepon bagi pertumbuhan ekonomi tidaklah begitu besar.

4. Air Bersih mempunyai hubungan yang positif dan signifikan terhadap pertumbuhan ekonomi, semakin banyak dan baik kualitas penyaluran air bersih yang memenuhi kaidah-kaidah teknis dan ekonomis sesuai dengan standar kriteria yang telah ditentukan maka akan dapat meningkatkan pertumbuhan ekonomi.

\section{Saran}

1. Dengan semakin meningkatnya panjang jalan di Provinsi Bengkulu, diharapkan kepada pemerintah sebaiknya lebih mengawasi penggunaan jalan yang digunakan kendaraan dengan muatan yang melebihi kapasitas yang tidak sesuai dengan kamampuan ketahanan jalan maupun pemeliharaan rutin. Sehingga kondisi jalan dapat terjaga dengan baik dan bertahan dengan waktu yang cukup lama. Sehingga masyarakat yang melakukan distribusi barang dan jasa dapat berjalan dengan lancar dan pertumbuhan ekonomi yang diharapkan semakin meningkat setiap tahunnya.

2. Agar dapat meningkatkan penyaluran energi listrik di Provinsi Bengkulu. Ketersediaan pasokan listrik harus cukup dan merata pada setiap wilayah. Diharapkan kepada pemerintah untuk lebih memaksimalkan ketersediaan listrik, perbaikan listrik dan penambahan daya di Provinsi Bengkulu.Karena penggunaan listrik ini bukan hanya untuk kegiatan rumah tangga namun juga untuk kegiatan industri. Jadi listrik merupakan salah satu faktor penting bagi peningkatan pertumbuhan ekonomi.

3. Dengan adanya hubungan negatif antara penyaluran Telepon terhadap pertumbuhan ekonomi, Pihak PT.Telkom Provinsi Bengkulu perlu membuat terobosan terbaru seperti perbaikan teknologi dengan penyediaan promo dengan pemasangan telepon per paket menggunakan jaringan internet maupun jaringan televisi. Disediakan juga harga diskont untuk pemasangan telepon pertama, sehingga harga yang ditawarkan cukup terjangkau dan dapat menarik minat masyarakt untuk menggunakan telepon.

4. Meskipun secara kualitas penyaluran air bersih kurang sesuai dengan kaidah-kaidah dan standar kualitas yang telah ditetapkan namun air bersih berpengaruh signifikan terhadap pertumbuhan 
ekonomi di Provinsi Bengkulu. Seyogyanya hal tersebut harus disertai dengan upaya peningkatan kualitas air bersih yang disalurkan oleh PDAM, misalnya air yang disalurkan harus memenuhi kaidahkaidah teknis dan ekonomis sesuai dengan standar kriteria yang telah ditentukan. Mengadakan penyuluhan dan memberikan penjelasan kepada masyarakat, bahwa begitu pentingnya konsumsi air bersih. Sehingga diharapkan kepada masyarakat untuk tidak membuang sampah sembarangan di aliran air PAM dan dapat menjaga kebersihannya.

\section{DAFTAR PUSTAKA}

Andriani, Evanti. S. 2013. "Analisis Peran Infrastruktur terhadap Pertumbuhan Ekonomi Provinsi Jawa Barat".

Arsyad, Lincolin. 1997. “Ekonomi Pembangunan” Aditya Media. Yogyakarta.

Alfirman, Luky. 2006. "Analisis Hubungan Pengeluaran Pemerintah dan Produk Domestik Bruto dengan Menggunakan Pendekatan Granger Causality", Jurnal Keuangan Publik.

Alson, Robby. 2009. "Analisa Investasi Infrastruktur terhadap Pertumbuhan Ekonomi", Penelitian . Institut Teknologi Sepuluh Nopember. Surabaya.

Badan Pusat Statistik (BPS). Publikasi “Sumber Air Minum”, 2008 - 2013. Bengkulu.

BPS. 2009. Provinsi Bengkulu Dalam Angka Angka 2009. Bengkulu, BPS.

2010. Provinsi Bengkulu Dalam Angka Angka 2010. Bengkulu, BPS.

2011. Provinsi Bengkulu Dalam Angka Angka 2011. Bengkulu, BPS.

2012. Provinsi Bengkulu Dalam Angka Angka 2012. Bengkulu, BPS.

2013. Provinsi Bengkulu Dalam Angka Angka 2013. Bengkulu, BPS.

Bulkin, Imron. 1997. "Antisifasi Kebutuhan Infrastruktur di Indonesia, 1990 - 2020”, Dalam Bunga Rampai Perencanaan Pembangunan di Indonesia. Jakarta: PT Grasindo.

Basyir, Arman. 2007. "Pengaruh Pembangunan Infrastruktur terhadap PDRB di Provinsi Maluku Utara tahun 2001 - 2006" Tesis. UGM. Yogyakarta.

Domar, Harrod. 1947. "Menganalisis Syarat-syarat Perekonomian Bisa Tumbuh dan Berkembang dalam Jangka Panjang".

Ernawi, Imam. 2007. "Peranan Penataan Ruang Dalam Dimensi Nasional dan Wilayah Perkotaan Sebagai Piranti Dalam Pemilihan Kebijaksanaan Investasi Bidang Jalan".

Hidayatullah, Syrif. 2012. "Pengaruh Infrastruktur Terhadap Pertumbuhan Ekonomi di Indonesia". Tesis. IPB. Bogor.

Kasim. S.T. 2006. "Analisis Pengaruh Kinerja Infrastrktur Listrik terhadap Pertumbuhan Ekonomi Indonesia. Tesis Universitas Sumatera Utara", Medan.

Koyck. 1954. "Mengestimasi Hubungan Peubah tidak Bebas (dependent) dengan Peubah Bebas (independent)".

Mankiw, N. G. 2007. Makroekonomi. Edisi Keenam. Erlangga, Jakarta.

Mawardi, Dedi. 2004. "Hubungan antara infrastruktur ekonomi dan pertumbuhan PDRB di Jawa Timur dengan menggunakan pendekatan model persamaan produksi COO - Douglas". Tesis. Universitas Kristen Petra. Jakarta.

Nurhidayanti, Desti. 2014. "Pengaruh Infrastruktur Terhadap Pertumbuhan Ekonomi di Sukabumi".

Oktavian, Eko. 2004. "Analisis Pengeluaran Pemerintah di Bidang Infrastruktur Studi Kasus Pemerintahan Kabupaten Musi Banyuasin Provinsi Sumatera Selatan". Kajian Ekonomi Vol 3 (2) 1983 - 2006.

Firdaus, Muhammad dan Prasetyo, "Rindang Bangun. 2009. Pengaruh Pada Pertumbuhan Ekonomi Wilayah Di Indonesia"Tesis Magister Sains. IPB. Bogor. 2(2):222-236.

Rusmansyah. 2006. "Arahan Pengembangan Kawasan Barat Kabupaten Bangka". Tesis. Program Pasca Sarjana Universitas Diponegoro, Semarang mbak tina.

Sari, Perwita. 2009. "Pengaruh Pembangunan Infrastruktur Terhadap Pertumbuhan Ekonomi 25 Kabupaten Tertinggal Kawasan Timur Indonesia". Skripsi. IPB. Bogor.

Sibarani. 2002. "Kontribusi Infrastruktur terhadap Pertumbuhan Ekonomi Indonesia". Tesis Magister Sains. Program Pascasarjana, Universitas Indonesia, Jakarta.

Setiawan, Iwan. 2006. "Analisis Akses Desa-desa di Kabupaten Bandung Terhadap Sumber-sumber Produktif". Laporan Penelitian. UNPAD.

Simanjutak, Payaman J. 1985. "Pengantar Ekonomi Sumber Daya Manusia", Jakarta. Fakultas Ekonomi Universitas Indonesia.

Sirojuzilam, 2009. "Disparitas Ekonomi Regional dan Perencanaan Wilayah", Rapat Terbuka Universitas Sumatera Utara.

Sukirno, S. 2004. Makroekonomi Teori Pengantar. PT Raja Grafindo Persada, Jakarta.

Todaro, M. P dan S. C. Smith. 2006. Pembangunan Ekonomi. Edisi kesembilan. Erlangga, Jakarta. 
The World Bank. 1994. World Development Report:Infrastructure for Development. Oxford University Press, New York.

Universitas Bengkulu, "Buku Panduan Penulisan Tesis".

Wahyuni, Tri. 2008. Analisis Pengaruh Infrastruktur Ekonomi dan Sosial terhadap Produktivitas Ekonomi di Indonesia". Tesis. Universitas Sumatera Utara. 